\title{
Epigeal invertebrate fauna in monoculture and integrated systems in the cerrado
}

\section{biome Piauí}

\author{
Fauna epígea invertebrada em monocultivos e sistemas integrados no cerrado piauiense \\ Fauna epigea invertebrada en monocultivos y sistemas integrados en el cerrado de Piauí
}

Received: 03/14/2021 | Reviewed: 03/21/2021 | Accept: 03/23/2021 | Published: 04/01/2021

\author{
João Rodrigues da Cunha \\ ORCID: https://orcid.org/0000-0001-6990-3361 \\ Universidade Federal do Piauí, Brazil \\ E-mail: joaorcsolos@hotmail.com \\ Adriano Veniciús Santana Gualberto \\ ORCID: https://orcid.org/0000-0002-1764-5564 \\ Universidade Federal do Piauí, Brazil \\ E-mail: a.vsg@hotmail.com \\ Renato Falconeres Vogado \\ ORCID: https://orcid.org/0000-0003-3282-7363 \\ Universidade Federal da Paraíba, Brazil \\ E-mail: renatoagro86@hotmail.com \\ Henrique Antunes de Souza \\ ORCID: https://orcid.org/0000-0002-2209-4285 \\ Empresa Brasileira de Pesquisa Agropecuária, Brazil \\ E-mail: henrique.souza@embrapa.br \\ Luiz Fernando Carvalho Leite \\ ORCID: https://orcid.org/0000-0001-9648-705X \\ Empresa Brasileira de Pesquisa Agropecuária, Brazil \\ E-mail: luiz.f.leite@embrapa.br
}

\begin{abstract}
Epigeal fauna are considered key biological indicators of soil quality, which can be used as parameters for determining sustainable agricultural production systems. This study aimed to evaluate the epigeal fauna under different monoculture and integrated production systems in a Yellow Latosol in the Cerrado biome. The epigeal fauna was sampled using pitfall traps in areas of no-tillage, pasture, exclusive eucalyptus cultivation, integrated livestock-forest system and in a native cerrado. The following variables were determined: number of individuals $\operatorname{trap}^{-1}$ day $^{-1}$, total richness and the indices of Shannon and Pielou. The number of individuals $\operatorname{trap}^{-1} \mathrm{day}^{-1}$ and richness were higher in native cerrado, while the no-tillage area presented the lowest values. For the Shannon and Pielou indices, native cerrado and integrated livestock-forest system presented the highest values while exclusive eucalyptus cultivation and no-tillage presented the lowest values. The pasture, exclusive eucalyptus cultivation and integrated livestock-forest system favored the ecological indexes of the epigeal fauna, while no-tillage was the system that least contributed to the establishment of these organisms. In areas explored with pasture, exclusive eucalyptus cultivation and integrated livestock-forest system, the community and the diversity of groups of fauna tend to increase. The association with different groups of fauna is more expressive in environments of native cerrado and exclusive eucalyptus cultivation.
\end{abstract}

Keywords: Biological indicators; Livestock-forest integration; Collembola.

\section{Resumo}

A fauna epígea é um importante bioindicador de qualidade do solo, o que possibilita o seu uso como instrumento na determinação de sistemas de produção sustentáveis na agropecuária. Objetivou-se com este trabalho avaliar a comunidade da fauna epígea sob diferentes monocultivos e sistemas integrados de produção. A fauna epígea foi coletada em áreas de plantio direto, pastagem, cultivo exclusivo de eucalipto, sistema de integração pecuária-floresta e em uma área cerrado nativo, como referência, utilizando armadilhas do tipo "Pitfall", para avaliação do o número de indivíduos armadilha ${ }^{-1}$ dia $^{-1}$, a riqueza total e os índices de Shannon e Pielou. O número de indivíduos por armadilha ao dia e a riqueza foram maiores no cerrado nativo, enquanto o plantio direto apresentou os menores valores. Quanto ao índice de Shannon e de Pielou, o cerrado nativo e o sistema de integração pecuária-floresta apresentaram os maiores valores, e o cultivo exclusivo de eucalipto e o plantio direto os menores. A pastagem, cultivo exclusivo de eucalipto e a integração pecuária-floresta favorecem os índices ecológicos da fauna epígea, enquanto plantio direto foi o sistema que menos contribui para o estabelecimento da fauna epígea. O cerrado nativo e o cultivo exclusivo de eucalipto mostraram associação com diversos grupos da fauna epígea, enquanto que o plantio direto apresentou afinidade apenas com o grupo larva de Lepidoptera. 
Palavras-chave: Indicador biológico; Integração-pecuária-floresta; Collembola.

\section{Resumen}

La fauna epigeana es un importante bioindicador de la calidad del suelo, lo que permite su uso como instrumento para determinar los sistemas de producción sostenible en la agricultura. El objetivo de este trabajo fue evaluar la comunidad de fauna epígea bajo diferentes monocultivos y sistemas de producción integrados. La fauna epigeana fue recolectada en áreas de labranza cero, pastos, cultivo exclusivo de eucalipto, sistema de integración ganadero-bosque y en un área de cerrado nativo, como referencia, utilizando trampas "pitfall", para evaluar el número de individuos trampa ${ }^{-1}$ día $^{-1}$, la riqueza total y los índices de Shannon y Pielou. El número de individuos por trampa por día y riqueza fue mayor en el cerrado nativo, mientras que el labranza cero presentó los valores más bajos. En cuanto al índice de Shannon y Pielou, el cerrado nativo y el integración ganadero-bosque tuvieron los valores más altos, y el cultivo exclusivo de eucalipto y el labranza cero los más bajos. Pastos, cultivo exclusivo de eucalipto e integración ganadero-bosque favorecen los índices ecológicos de la fauna epigea, mientras que la labranza cero es el sistema que menos contribuye al establecimiento de la fauna epigea. El cerrado nativo y el cultivo exclusivo de eucalipto mostraron asociación con varios grupos de fauna epígea, mientras que el labranza cero mostró afinidad solo con el grupo de larvas de Lepidoptera.

Palabras clave: Indicador biológico; Integración-ganadería-forestal; Collembola.

\section{Introduction}

In the Cerrado biome located in Piauí, Northeast Brazil, there has been intensive soil use with continuous applications of correctives (e.g. lime, gypsum), fertilizers and agrochemicals. Such practices cause severe changes in soil properties (Braz et al., 2013), compromising the sustainability of the ecosystem and deteriorating the biological component of the soil, such as the composition of the epigeal invertebrate fauna (Lima et al., 2019; Bartz et al., 2014).

The different groups of the epigeal soil fauna are of fundamental importance for the maintenance of soil quality because they participate in important ecological processes, performing various environmental functions, such as the litter fragmentation, organic matter decomposition, biorecycling and redistribution of nutrients between the different soil layers and gallery opening (Choudhary et al., 2018; Bartz et al., 2014).

In addition to its ecological function, the invertebrates are considered important bioindicators of soil quality due to their high sensitivity to impacts caused by different management and land use systems. Thus, the epigeal fauna can be used as parameters for determining sustainable agricultural production systems (Santos et al., 2016). The indications of soil management systems that promote greater biological conservation can be done by assessing the disturbance levels of invertebrate fauna, observing a decline the abundance and diversity of species, in addition to the change in the fauna composition from o non disturbed, as well as the presence of certain specific groups (Souza et al., 2016; Silva et al., 2012).

The importance of these invertebrates has been emphasized for maintaining soil quality and the environment in the Cerrado biome (Lima et al., 2019; Santos et al., 2016; Portilho et al., 2011; Silva et al., 2011). However, there is still a lack of information on their behavior in anthropized areas and especially with eucalyptus cultivation (Souza et al., 2016; Cortez et al., 2015; Vargas et al., 2013). Moreover, more studies are needed regarding areas involving production systems with the use of eucalyptus, both in monoculture and in integrated systems, aiming at understanding the effects of different management systems and land uses on epigeal fauna.

This study aimed to evaluate the epigeal fauna community under different monoculture and integrated production systems in a Yellow Latosol in the Cerrado biome located in Piauí, Brazil.

\section{Methodology}

The study was conducted at Fazenda Chapada Grande, located in Regeneração, Piauí state, Brazil $\left(06^{\circ} 21^{\prime} 03^{\prime \prime}\right.$ S, $42^{\circ} 28^{\prime} 79^{\prime \prime} \mathrm{W}, 374 \mathrm{~m}$ of altitude). The climate of the region is classified as Aw, according to the Köppen classification, composed of hot and humid tropical weather, with rainy summers and dry winters. The annual average temperature is $26.4{ }^{\circ} \mathrm{C}$ and the 
annual average rainfall is $1,371 \mathrm{~mm}$. The chemical attributes of the soil, which is classified as Dystrophic Yellow Latosol (Jacomine et al., 1986), are shown in Table 1.

Table 1. Chemical attributes of the 0-0.1 m layer of a Dystrophic Yellow Latosol under different management systems in the Cerrado region of Piauí, Brazil.

\begin{tabular}{ccccccccc}
\hline $\begin{array}{c}\text { Management } \\
\text { systems }\end{array}$ & $\mathbf{p H}$ & $\mathbf{P}$ & $\mathbf{K}^{+}$ & $\mathbf{C a}^{+2}$ & $\mathbf{M g}^{+2}$ & $\mathbf{A l}^{+3}$ & $\mathbf{C l a y}$ & $\mathbf{O M}$ \\
\hline $\mathrm{NC}$ & $\left(\mathrm{H}_{2} \mathrm{O}\right)$ & $\left(\mathrm{mg} \mathrm{dm}^{-3}\right)$ & \multicolumn{2}{c}{$---------\left(\mathrm{cmol}_{\mathrm{c}} \mathrm{dm}^{-3}\right)-------$} & $----\left(\mathrm{g} \mathrm{kg}^{-1}\right)----$ \\
$\mathrm{NT}$ & 4.6 & 8.1 & 0.1 & 1.4 & 0.0 & 1.9 & 506 & 38.4 \\
$\mathrm{PAS}$ & 5.6 & 30.0 & 0.4 & 4.0 & 0.9 & 0.3 & 608 & 41.2 \\
$\mathrm{EEC}$ & 6.0 & 17.8 & 0.3 & 4.1 & 0.7 & 0.1 & 635 & 46.3 \\
$\mathrm{LFI}$ & 5.7 & 9.4 & 0.1 & 3.7 & 0.1 & 2.2 & 571 & 52.6 \\
\hline
\end{tabular}

OM - organic matter; NC: native cerrado; NT: no-tillage; PAS: pasture; EEC: eucalyptus exclusive cultivation and LFI: livestock-forest integration system. Source: Authors.

Four different soil management systems were selected for the study: no-tillage (NT), pasture (PAS), exclusive eucalyptus cultivation (EEC), integrated livestock-forest system (LFI) and a native Cerrado (NC) area, which was used as reference.

In the NT area, deforestation occurred in 2010, and the initial tillage consisted plowing and root incorporation of $4 \mathrm{tha}$ ${ }^{1}$ of dolomitic limestone and fertilization with $250 \mathrm{~kg} \mathrm{ha}^{-1}$ of NPK. The area was cultivated with rice in 2011 and with soybean in 2012 under a conventional system, which weas later converted into no-tillage and crop rotation (soybean and corn) systems. During sampling, the area in this system was cultivated with soybeans.

The Pasture (PAS) was implemented in 2008 by using plowing and liming applications. The pasture was formed with Urochloa brizantha grass, which was subjected to rotational grazing by Nellore cattle with a stocking rate of $1 \mathrm{UA} \mathrm{ha}^{-1}$ year $^{-1}$ for 15 days in each paddock.

For the exclusive eucalyptus cultivation (EEC) system, planting was carried out in 2007 using MA-2000 clones, with spacing of $2 \mathrm{~m}$ between plants in rows and $3 \mathrm{~m}$ between rows after soil preparation. In this system, $2 \mathrm{tha}^{-1}$ of dolomitic limestone, $150 \mathrm{~kg} \mathrm{ha}^{-1}$ of NPK (06-30-06) and $110 \mathrm{~kg} \mathrm{ha}^{-1}$ of NPK (22-00-22) were applied.

The integrated livestock-forest (LFI) system was formed by the intercropping of eucalyptus and Urochloa brizantha grass. Eucalyptus was planted in 2011, with $2 \mathrm{~m}$ spacing between plants in three rows and $3 \mathrm{~m}$ and $30 \mathrm{~m}$ between rows, using MA-2000 clones. A total of $2 \mathrm{t} \mathrm{ha}^{-1}$ of dolomitic limestone, $150 \mathrm{~kg} \mathrm{ha}^{-1}$ of NPK (06-30-06) and $110 \mathrm{~kg} \mathrm{ha}^{-1}$ of NPK (22-00-22) were applied. In this system, rotational grazing with Nellore cattle with a stocking rate of $1 \mathrm{UA} \mathrm{ha}^{-1} \mathrm{year}^{-1}$ for 15 days in each paddock was adopted. The Cerrado area is composed of herbaceous, shrub, arboreal vegetation and vines typical of this biome, especially trees with tortuous stems.

Sampling of epigeal fauna was carried out in February 2017, using pitfall traps, according to the methodology described by Moldenke (1994), adapted by Aquino et al. (2006). The traps constituted of plastic containers $10 \mathrm{~cm}$ high and diameter of 10 $\mathrm{cm}$, which were buried in the ground with the edge at the level of the soil surface. Seven traps were installed per soil management system. In each trap, $200 \mathrm{~mL}$ of a preservative solution based on $4 \%$ formaldehyde were added to prevent deterioration of the invertebrates. After seven days, the traps were removed from the soil and the collected individuals were identified at the level of order or class (Dindal, 1990; Gallo, 1988). 
Data analysis was performed by calculating the number of individuals trap ${ }^{-1}$ day $^{-1}$ and richness. Ecological indexes of richness (S) and Shannon-Weaner $(\mathrm{H})$ were also calculated:

$$
\mathrm{H}=-\sum \mathrm{pi} * \log \mathrm{pi} \text {, (Equation 1) }
$$

Where: $\mathrm{pi}=\mathrm{ni} / \mathrm{N}$; $\mathrm{ni}$ is the abundance of each fauna group; $\mathrm{N}$ is the total abundance.

It was calculated Pielou'sindex equitability (e):

$$
\mathrm{e}=\mathrm{H} / \log \mathrm{S} \text {, (Equation 2) }
$$

where: $\mathrm{H}$ is the Shannon-Weaner index; $\mathrm{S}$ is the richness.

The organisms were divided into functional groups based on characteristics of habitat use and the main form of food resources use, being classified into: Decomposers, Engineers and Predators, according to the classification of (Merlim et al., 2005) and (Brown et al., 2009).

The number of individuals trap ${ }^{-1}$ day $^{-1}$ and the richness of the groups were subjected to the Shapiro-Wilk and Barllet's tests to verify the normality and homogeneity of the data. As they did not meet the assumptions of the analysis of variance, the data were subjected to non-parametric analysis, using the Friedman test at 5\% significance level. Principal component multivariate analysis (PCA) was carried out between the taxonomic groups and the soil management systems, using the statistical software R (R Development Core Team, 2016).

\section{Results and Discussion}

\subsection{Diversity e population of fauna}

The number of individuals trap ${ }^{-1}$ day $^{-1}$, which represents the abundance of epigeal fauna organisms, differed significantly ( $\leq 0.05$ ) between the systems, with the highest value found in the $\mathrm{NC}$ area, while the lowest value was found in NT (Table 2).

Table 2. Number of individuals trap ${ }^{-1} \mathrm{day}^{-1}$ and ecological indexes of soil invertebrate fauna under different soil management systems in the Cerrado biome located in Piauí, Brazil.

\begin{tabular}{ccccc}
\hline $\begin{array}{c}\text { Management } \\
\text { systems }\end{array}$ & Ind Trap $^{-1}$ day $^{-1}$ & Richness & Shannon & Pielou \\
\hline NC & $25.7 \mathrm{a}^{1}$ & $18 \mathrm{a}$ & 2.7 & 0.6 \\
NT & $3.6 \mathrm{c}$ & $5 \mathrm{c}$ & 0.9 & 0.4 \\
PAS & $19.2 \mathrm{ab}$ & $14 \mathrm{ab}$ & 2.4 & 0.6 \\
EEC & $13.6 \mathrm{~b}$ & $12 \mathrm{~b}$ & 2.1 & 0.6 \\
LFI & $11.8 \mathrm{bc}$ & $11 \mathrm{~b}$ & 2.5 & 0.7 \\
\hline Test F & $20.3^{*}$ & $35.9^{*}$ & - & - \\
\hline VC\% & 32.9 & 21.8 & - & - \\
\hline
\end{tabular}

${ }^{1}$ Means followed by the same letter in the column do not differ from each other according to the Friedman test $(\mathrm{p} \leq 0.05) \mathrm{NC}$ : native cerrado; NT: no-tillage; PAS: pasture; EEC: exclusive eucalyptus cultivation; LFI: integrated livestock-forest integration. Source: Authors.

The highest values of individuals per trap observed in NC can be attributed to the presence of litter from a diversity of plant species, which can be used as a source of food for edaphic organisms (Bartz et al., 2014). According to Hedde et al. (2015), the more diverse the vegetation cover, the greater the heterogeneity of the litter, which may favor the establishment of a larger population fauna organisms. In addition, in areas of native vegetation there is a greater number of ecological niches and less competition between species. In the PAS, what may have contributed to the high values, may be the presence of the brachiaria 
that produces a large amount of organic waste to the soil due to the high biomass production of the aerial part and its extensive root system and in constant renovation (Nunes et al., 2012). These plant residues serve as a food source often creating a microclimate favorable to the soil invertebrates, resembling a natural forest environment. The lower abundance of epigeal fauna in the NT, system might be due to the applications of herbicides and insecticides, as reported by Mentone et al. (2011). In addition, the short time of adoption of this system and the low amount of plant residues left in the soil is still not configured as an environment favorable to the emergence of habitats for the colonization of the fauna.

The richness differed between treatments, with the highest values being observed in NC, followed by the PAS. The lowest value was found in NT. These results were similar to those found by Silva et al. (2011), when evaluating the edaphic fauna using soil monoliths in different management systems in a Cerrado area in Mato Grosso do Sul, Brazil. The same pattern was obtained by Nunes et al. (2012), who observed higher values of richness in a pasture area (Tifton grass) when compared to the other studied systems. The authors emphasized that Tifton grass provides considerable organic input resulting from permanent renewal, which promotes litter formation. Thus, it can be inferred that pasture provides favorable conditions to increase the diversity of invertebrate fauna when well managed, which consequently is considered an important biological indicator of soil quality.

In relation to the Shannon diversity index, NC, PAS and LFI presented higher values than NT and EEC. The greater diversity of fauna individuals in these systems might be associated with the quality of the organic residues in the soil. In addition, in NC and LFI the tree component provides shade areas, creating a microclimate favorable to edaphic invertebrates. In PAS, the greater diversity of fauna organisms can be attributed to the considerable release of organic residues resulting from the permanent renewal by the death of plant roots and shoot, which contributes to the establishment of a greater number of taxonomic groups (Lima et al., 2019; Nunes et al., 2012). The value of diversity in NT might also reflect the changes imposed by the preparation of the soil with plowing and harrowing operations inherited from the conventional system practiced in the studied areas in previous years. These practices can cause habitat destruction, the elimination of available food and edaphoclimatic conditions favorable to soil invertebrates. In addition the lower diversity of fauna groups in NT system can be attributed to the low supply in the low quality of cultural residues found in this system at the time of sampling, also verified by Souza et al. (2016) and Baretta et al. (2014) .

The highest value of the Pielou index in LFI is related to the high occurrence of the groups Collembola, Coleoptera and Formicidae. The Pielou index varies between 0 and 1, and the lower the obtained value, the greater the dominance of a few groups (Pasqualin et al., 2012). The low Pielou value for NT was due to the high frequency of the Coleoptera group, with percentages up to $80 \%$, showing total dominance of this group in this system. On the other hand, in EEC the value of uniformity is related to the predominance of the Collembola group, which presented a frequency of nearly $60 \%$. This frequency might have been conditioned by the high amount of litter input in this system, composed of decomposing organic waste. According to Verma et al. (2014) Collembola organisms are predominant in moist soils and under decaying fallen leaves. Abreu et al. (2014) recorded similar variations when evaluating the epigeal fauna in other soil management systems.

Regarding the relative distribution of epigeal fauna, the groups Coleoptera and Formicidae were present in greater proportions in all the management systems studied. In the EEC, in addition to the predominance of the Coleoptera and Formicidae groups, there was also a great predominance of the Collembola group (Table 3). 
Table 3. Relative distribution of epigeal fauna communities under different management systems in the Cerrado biome located in Piauí, Brazil.

\begin{tabular}{|c|c|c|c|c|c|}
\hline \multirow{2}{*}{ Groups } & NC & NT & PAS & EEC & LIF \\
\hline & \multicolumn{5}{|c|}{ 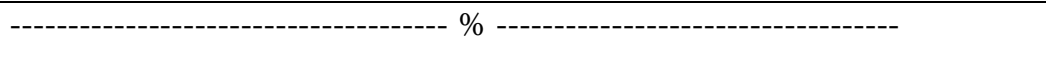 } \\
\hline Araneae & 7.3 & 0.0 & 2.2 & 1.2 & 0.7 \\
\hline Blattodae & 1.7 & 0.0 & 0.1 & 1.5 & 1.7 \\
\hline Collembola & 5.8 & 0.0 & 12.3 & 61.5 & 31.6 \\
\hline Coleoptera & 18.6 & 81.1 & 26.0 & 10.7 & 34.9 \\
\hline Dermaptera & 0.1 & 0.0 & 0.8 & 1.9 & 1.9 \\
\hline Diplopoda & 3.6 & 0.0 & 10.3 & 0.0 & 18.6 \\
\hline Formicideae & 31.2 & 9.7 & 4.3 & 9.9 & 38.9 \\
\hline Isopoda & 4.8 & 0.0 & 0.0 & 0.0 & 0.0 \\
\hline Isoptera & 12.9 & 0.6 & 0.1 & 1.2 & 0.0 \\
\hline Coleoptera larva & 2.9 & 0.0 & 0.5 & 0.0 & 0.0 \\
\hline Lepidoptera & 0.1 & 0.0 & 0.0 & 0.0 & 0.2 \\
\hline Oligochaeta & 0.1 & 8.0 & 4.6 & 0.0 & 0.0 \\
\hline Orthoptera & 0.5 & 0.0 & 1.3 & 0.4 & 0.0 \\
\hline Others* & 0.4 & 0.6 & 1.3 & 7.1 & 2.9 \\
\hline
\end{tabular}

*Diptera, Tyssanura; Lepidoptera larva; Neuroptera larva;. NC: native Cerrado; NT: no-tillage; PAS: pasture; EEC: exclusive eucalyptus cultivation; LFI: integrated livestock-forest integration. Source: Authors.

The predominance of the Formicidae and Coleoptera groups in all systems is in line with the results found by Lima et al. (2019), studying epigeal fauna in different management systems in the Piauí semi-arid region. Cortez et al. (2015), also found a greater predominance of the groups of Formicidae and Coleoptera, when evaluating the epigeal fauna eucalyptus crop with different ages in the cerrado of Piauí. These authors attributed the results to greater resistance and adaptation of these groups to the climatic conditions the of region. These results help explain the greater dominance of these groups of epigeal fauna in the present work. The order Coleoptera constitutes a large group and with diversity of species with great rusticity (Farias et al., 2015) occurring in different ecological niches and that present quite diversified eating habits. Due to this characteristic, it is one of the most abundant orders in Brazilian soils. The results observed in the present study are in agreement with other studies for Cerrado conditions, which showed great abundance of this group, regardless of the management methods and the time of assessment (Portilho et al., 2011; Vargas et al., 2013). Although some families of this order are considered pests in agriculture both at larval and adult stages, they can be beneficial for soil fertility and physics (Portilho et al., 2011).

The high frequency of the Formicidae group might be associated with the fact that these organisms are very abundant and dominant in terrestrial ecosystems, indicating that this group has the capacity to adapt to different changes in the environment (Mentone et al., 2011). Other authors have also reported a high frequency of the Formicidae group in studies of epigeal fauna in different soil management systems (Pasqualin et al., 2012; Vargas et al., 2013). This group is of relevant importance for maintaining soil quality because it performs several processes. In addition, the complexity of galleries and chambers of the anthills increases the porosity and the drainage capacity of the soil, decreasing soil density (Mentone et al., 2011).

The predominance of the Collembola group in EEC is due to the presence of a dense litter layer composed of decomposing organic waste. These organisms feed mainly on decomposing organic materials and microorganisms, such as fungi and bacteria (Verma et al., 2014). Martins et al. (2017) also verified high abundance of Collembola in monoculture of eucalyptus. 


\subsection{Classification of epigeal fauna organisms}

Regarding the functional groups of the soil epigeal fauna, the decomposers were the ones with the highest density. The main representatives were the Acari, Collembola and Diplopoda groups (Table 4).

Table 4. Average number of individuals of the invertebrate fauna of the soil, classified according to its functionality in different soil management systems in the Cerrado biome located in Piauí, Brazil.

\begin{tabular}{ccccccc}
\hline & NC & NT & PAS & EEC & LFI & Value F \\
\hline Decomposers $^{I}$ & & & & & & \\
Acari & $21.8 \mathrm{bc}$ & - & - & $1588.1 \mathrm{a}$ & $278.7 \mathrm{~b}$ & $113.2^{*}$ \\
Collembola & $9.5 \mathrm{~b}$ & - & $16.6 \mathrm{~b}$ & $60.0 \mathrm{a}$ & $26.1 \mathrm{~b}$ & $9.1^{*}$ \\
Diplopoda & $6.6 \mathrm{~b}$ & - & $13.8 \mathrm{a}$ & - & $15.4 \mathrm{a}$ & $9.1^{*}$ \\
Isopoda & 7.7 & - & - & - & - & - \\
\hline Engineers & & & & & & \\
Formicidae & $58.5 \mathrm{a}$ & $2.4 \mathrm{c}$ & $54.1 \mathrm{a}$ & $9.8 \mathrm{c}$ & $32.1 \mathrm{~b}$ & $34.5^{*}$ \\
Isoptera & $23.7 \mathrm{a}$ & $0.1 \mathrm{~b}$ & $0.1 \mathrm{~b}$ & $1.1 \mathrm{~b}$ & - & $48.5^{*}$ \\
Oligochaeta & 0.1 & 2.0 & 6.1 & - & - & $2.5^{\mathrm{ns}}$ \\
\hline Predators & & & & & & \\
Araneae & $13.0 \mathrm{a}$ & - & $3.0 \mathrm{~b}$ & $2.1 \mathrm{~b}$ & $0.6 \mathrm{~b}$ & $60.2^{*}$ \\
Chilopoda & 0.3 & - & 0.3 & - & - & $2.0^{\mathrm{ns}}$ \\
Dermaptera & 0.2 & - & 1.1 & 1.8 & 1.6 & $1.4^{\mathrm{ns}}$ \\
Diptera & 0.3 & - & 1.3 & 1.1 & 0.4 & $2.2^{\mathrm{ns}}$ \\
Scorpionida & - & - & - & 0.4 & - & - \\
\hline Others & $7.0 \mathrm{c}$ & $0.3 \mathrm{~d}$ & $1.0 \mathrm{~d}$ & $18.4 \mathrm{~b}$ & $30.7 \mathrm{a}$ & $92.3^{*}$
\end{tabular}

${ }^{1}$ Classification according to Merlim et al. (2005) and Brown et al. (2009). Averages were calculated using the Friedman test and compared on the same row. ns: not significant $*$ significant $(\mathrm{p} \leq 0.05)$. NC: native cerrado; NT: no-tillage; PAS: pasture; EEC: exclusive eucalyptus cultivation; LFI: integrated livestock-forest integration. Source: Authors.

The highest occurrences were recorded in EEC for the Acari group, differing $(\mathrm{p} \leq 0.05)$ from the other studied management systems. Similar behavior was also observed for Collembola in this same management system, which differed significantly $(\mathrm{p} \leq 0.05)$ from the others. The Acari edaphic group feeds on decomposing organic materials, which might explain its greater predominance in EEC. Mite species are largely considered parasites of plants and animals, however, some species show great relevance in the decomposition of organic matter, and presence of this group in large quantities can be considered as an indicator of soil biological condition (Baretta et al., 2014).

The ecosystem engineers were represented by the groups Formicidae, Isoptera and Oligochaeta. The first one differed $(p \leq 0.05)$ between the systems, presenting greater abundance in NC and PAS. The order Isoptera had the highest occurrence in NC. The Oligochaeta group was not captured in all systems, and did not differ $(p \leq 0.05)$ between the systems. Engineer organisms play an essential role in maintaining soil quality due to their effects on their aggregation, with the creation of biogenic structures, which can be galleries, nests, chambers and fecal acorns. It can significantly affect the physical properties of the soil and the availability of resources for other organisms (Anderson, 2009).

As for Predators, the presence of the groups Araneae, Dermaptera and Diptera, Diplopoda and Scorpionida was also observed, with Araneae showing greater predominance among the systems with greater density in NC. The greater amount of 
litter in this system promoted better conditions for the greater abundance of natural enemies (predators). The Araneae group plays a fundamental role in regulating populations of edaphic fauna, being considered an important tool in pest control. However, its density is strongly influenced by agricultural practices. According to Baretta et al. (2014), the areas with less anthropic action, such as natural vegetation, favor the appearance of spiders. In these areas, there is greater availability of food and conditions for web formation. On the other hand, the use of insecticides and chemicals in agricultural areas causes a reduction in the availability of prey (food) and the residual and repellent effect of some chemical substances that can provide a significant decrease in the spider community in agro-ecosystems.

\subsection{Principal component analysis}

Two principal components were decomposed from PCA, which explained $72.09 \%$ of the total variance of the data, which allowed for a two-dimensional ordering of the management systems and taxonomic groups of the epigeal fauna. The first component (PC1) presented $41.96 \%$ and component 2 (PC2) accounted for $30.13 \%$ of the data variability (Figure 1).

Figure 1. Projection diagram of the epigeal fauna vectors and ordering diagram of the principal components different management systems. NC: native cerrado; NT: no-tillage; PAS: pasture; EEC: eucalyptus exclusive cultivation e LFI: livestockforest integration system.

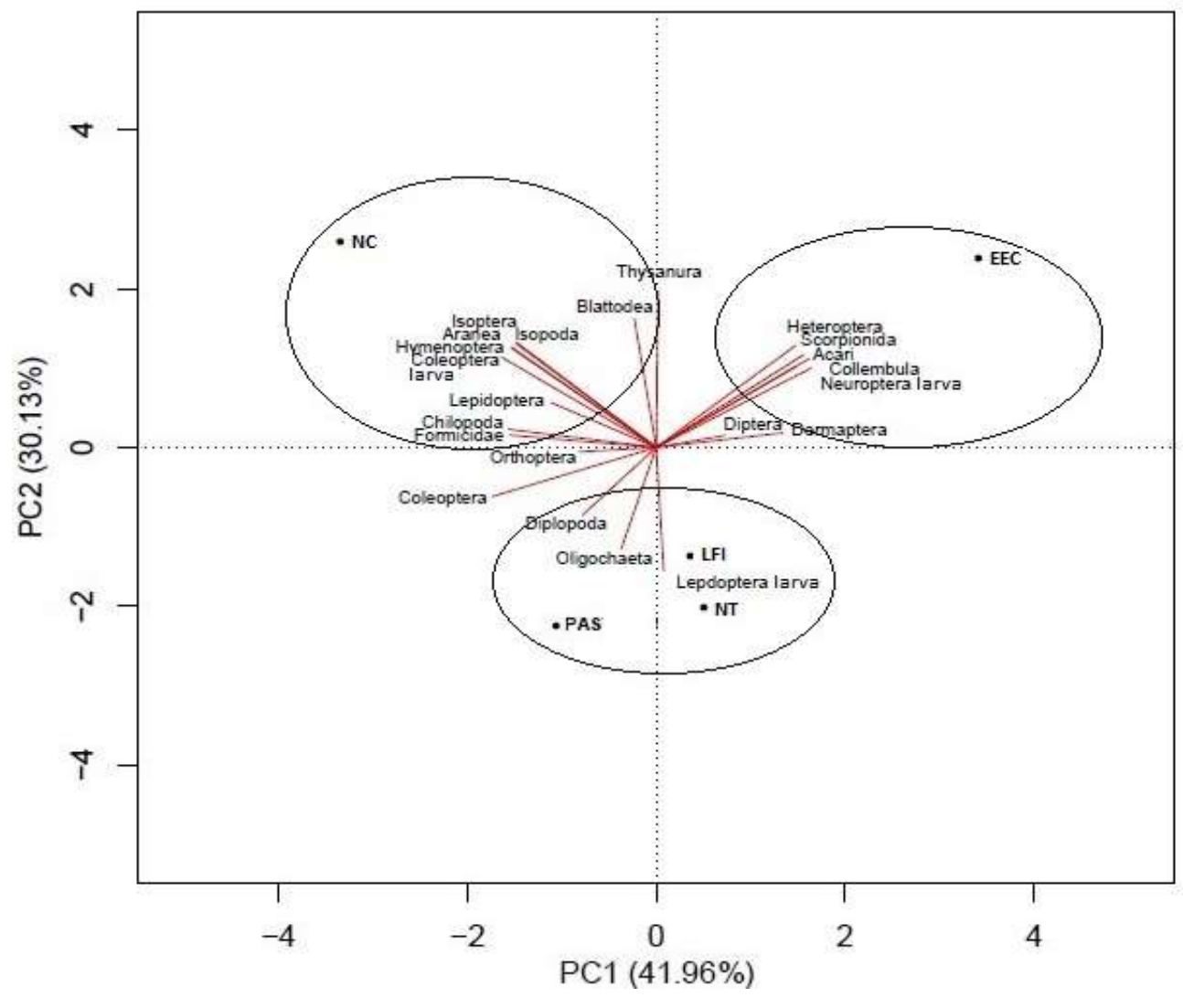

Source: Authors.

Through this two-dimensional ordering, it was possible to verify the formation of three groups, showing the distinct separation of $\mathrm{NC}$ from management systems with anthropic action, the isolation of EEC and the similarities between PAS, LFI and NT. The orders Isoptera, Araneae, Isopoda, Coleoptera Larva, Chilopoda, Hymenoptera, Lepdoptera and Formicidae presented a greater relationship with NC. A similar pattern was also obtained by Baretta et al. (2014); Bartz et al. (2014); Nunes et al. (2012), where such groups of invertebrate fauna showed greater abundance in native forest. The isolation of EEC is related 
to the great occurrence of the Acari group, which was much higher than that observed in the other systems and still because it has a low occurrence of the other groups in this system. The eucalyptus forest, despite being an environment with only one species of arboreal size, presents several shrub and herbaceous species in its understory, leaving the soil practically covered and providing a diversity of plant residues. In addition, the high density of some groups in EEC, such as Collembola and Acari, could have played a major role regarding this result.

Although the methodology used in the present study is not specific for the collection of organisms that live inside soil, the Oligochaeta group was collected at PAS. The capture of this group in this management system occurred as a result of the presence of feces from the animals that grazed in the area months before the installation of the traps. During the decomposition stage, these wastes favored even more the incidence of these organisms in this management system. According to Martínez and Sánchez (2002), animal waste increases the quality of organic matter, promoting greater carbon mineralization, favoring the development and establishment of these invertebrate fauna groups. The low relationship of NT with fauna groups might be a consequence of management practices carried out in this system in previous years. In addition, the low amount of residues for soil cover and the short adoption time for this management system were not sufficient to improve soil epigeal invertebrate fauna indicators.

\section{Conclusion}

In areas explored with pasture systems, exclusive eucalyptus cultivation and integrated livestock-forest, the community and the diversity of groups of epigeal fauna tend to increase.

The association with different groups of epigeal fauna is more expressive in environments of native cerrado and exclusive eucalyptus cultivation. The exclusive eucalyptus cultivation favors the increase of the community and the diversity of groups of epigeal fauna, as well as the association of this environment with different groups of this fauna.

For future research, it is recommended to use the pitfall and monolith methodologies together, in order to obtain greater robustness to the results. In addition, perform a multivariate analysis of main components involving soil fauna data and the physical, chemical and biological attributes of the soil.

\section{Acknowledgments}

The authors gratefully thank the National Council for Scientific and Technological Development (CNPq), the Fazenda Chapada Grande in the municipality of Regeneração from Piauí and Embrapa Meio-Norte.

\section{References}

Abreu, R. R. L., Lima, S. S., Oliveira, N. C. R., \& Leite, L. F. C. (2014). Fauna edáfica sob diferentes níveis de palhada em cultivo de cana-de-açúcar. Pesquisa Agropecuária Tropical, 44(4), 409-416. https://doi.org/10.1590/S1983-40632014000400002

Anderson, J. M. (2009). Why should we care about soil fauna? Pesquisa Agropecuária Brasileira, 44(8), 835-842. https://doi.org/0.1590/S0100$204 X 2009000800006$

Aquino, A. M., Aguiar-Menezes, E. L., \& Queiroz, J. M. (2006). Recomendação para coleta de artrópodes terrestres por armadilhas de queda (Pitfall traps): Embrapa Agrobiologia

Baretta, D., Bartz, M. L. C., Fachini, I., Anselmi, R., Zortéa, T., \& Baretta-Maluche, C. R. D. (2014). Soil fauna and its relation with environmental variables in soil management systems. Revista Ciência Agronômica, 45(5), 871-879. https://doi.org/10.1590/S1806-66902014000500002

Bartz, M. L. C., Brown, G. G., Rosa, M. G., Klauberg Filho, O., James, S. W., Decaëns, T., \& Baretta, D. (2014). Earthworm richness in land-use systems in Santa Catarina, Brazil. Applied Soil Ecology, 83(1), 59-70. https://doi.org/10.1016/j.apsoil.2014.03.003

Braz, A. M. S., Fernandes, A. R., \& Alleoni, L. R. F. (2013). Soil attributes after the conversion from forest to pasture in Amazon. Land Degradation and Development, 24(1), 33-38. https://doi.org/10.1002/ldr.1100 
Brown, G. G., Maschio, W., \& Froufe, L. C. M. (2009). Macrofauna do solo em sistemas agroflorestais e Mata Atlântica em regeneração nos municípios de Barra do Turvo, SP, e Adrianópolis, PR. Colombo, PR: Embrapa Florestas

Choudhary, M., Datta, A., Jat, H. S., Yadav, A.K., Gathala, M. K., Sapkota, T. B., \& Ladha, J. K. (2018). Changes in soil biology under conservation agriculture based on sustainable intensification of cereal systems in the Indo-Gangetic Plains. Geoderma, 313, 193-204. https://doi.org/10.1016/j.geoderma.2017.10.041

Cortez, C. T., Barbosa, L. R., Morais, G. P., Nunes, L. A. P. L., Araújo, A. S. F., \& Correia, M. E. F. (2015). Soil fauna under eucalypt stands of different ages in the Savanna of Piauí. Cientifica, 43(3), 280-286. https://doi.org/10.15361/1984-5529.2015v43n3p280-286

Dindal, D. (1990). Soil biology guide: John Wiley and Sons

Farias, P. M., Arellano, L., Hernández, M. I. M., \& Ortiz, S. L. (2015). Response of the copro-necrophagous beetle (Coleoptera: Scarabaeinae) assemblage to a range of soil characteristics and livestock management in a tropical landscape. Journal of Insect Conservation. 19, 947-960. https://doi.org/10.1007/s10841$015-9812-3$

Gallo, D. (1988). Manual de entomologia agrícola. (2a ed.), Agronômica Ceres

Hedde, M., Mazzia, C., Decaëns, T., Nahmani, J., Pey, B., Thénard, J., \& Capowiez, Y. (2015). Orchard management influences both functional and taxonomic ground beetle (Coleoptera, Carabidae) diversity in South-East France. Applied Soil Ecology, 88, 26-31. https://doi.org/10.1016/j.apsoil.2014.11.014

Lima, S. S., Benazzi, E. S., Oliveria, N. C. R., \& Leite, L. F. C. (2019). Diversidade da fauna epígea em diferentes sistemas de manejo no semiárido. Revista Agrarian, 12(45), 328-337. https://doi.org/10.30612/agrarian.v12i45.8975

Martínez, M. A., \& Sánchez, J. A. (2002). Comunidades de lombrices de tierra (Annelida: Oligochaeta) en un bosque siempre verde y un pastizal de Sierra del Rosario. Journal Science, 36(2), 94-103

Martins, L. F., Pereira, J. M., Tonelli, M., \& Barreta, D. (2017). Composição da macrofauna do solo sob diferentes usos da terra (cana-de-açúcar, eucalipto e mata nativa) em Jacutinga (MG). Revista Agrogeoambiental, 9(1), 11-22. https://doi.org/10.18406/2316-1817v9n12017913

Mentone, T. O., Diniz, E. A., Munhae, C. B., Bueno, O. C., \& Morini, M. S. C. (2011). Composition of ant fauna (Hymenoptera: Formicidae) at litter in areas of semi-deciduous forest and Eucalyptus spp., in Southeastern Brazil. Biota Neotropical, 11(2), 37-46. https://doi.org/10.1590/S1676-06032011000200024

Merlim, A. O., Guerra, J. G. M., Junqueira, R. M., \& Aquino, A. M. (2005). Soil macrofauna in cover crops of figs grown under organic management. Scientia Agricola, 62(1), 57-61. https://doi.org/10.1590/S0103-90162005000100011

Moldenke, A. R. (1994). Arthropods. In R. W. Weaver, Methods of soil analysis: microbiological and biochemical properties. SSSA

Nunes, L.A.P. L., Silva, D. I. B., Araújo, A. S. F., Leite, L. F. C., \& Correia, M. E. F. (2012). Caracterização da fauna edáfica em sistemas de manejo para produção de forragens no Estado do Piauí. Revista Ciência Agronômica, 43(1), 30-37. https://doi.org/10.1590/S1806-66902012000100004.

Pasqualin, L. A., Dionísio, J. A., Zawadneak, M. A. C., \& Marçal, C. T. (2012). Macrofauna edáfica em lavouras de cana-de-açúcar e mata no noroeste do Paraná - Brasil. Semina: Ciências Agrárias, 33(1), 7-18. https://doi.org/10.5433/1679-0359.2012v33n1p7

Portilho, I. I. R., Crepaldi, R. A., Borges, C. D., Silva, R. F., Salton, J. C., \& Mercante, F. M. (2011). Fauna invertebrada e atributos físicos e químicos do solo em sistemas de integração-lavoura-pecuária. Pesquisa Agropecuária Brasileira, 46(10),1310-1320. https://doi.org/10.1590/S0100-204X2011001000027

R Development Core Team. (2016). A Language and Environment for Statistical Computing. R Foundation for Statistical Computing.

Santos, D. P., Santos, G. G., Santos, I. L., Schossler, T. R., Niva, C. C., \& Marchão, R. L. (2016). Caracterização da macrofauna edáfica em sistemas de produção de grãos no Sudoeste do Piauí. Pesquisa Agropecuária Brasileira, 51(9), 1466-1475. https://doi.org/10.1590/S0100-204X2016000900045

Silva, R. F., Guimaraes, M. F., Aquino, A. M., \& Mercante, F. M. (2011). Análise conjunta de atributos físicos e biológicos do solo sob sistema de integração lavoura-pecuária. Pesquisa Agropecuária Brasileira, 46(10), 1277-1283. https://doi.org/10.1590/S0100-204X2011001000023

Silva, J., Jucksch, I. \& Tavares, R. C. (2012). Invertebrados edáficos em diferentes sistemas de manejo do cafeeiro na Zona da Mata de Minas Gerais. Revista Brasileira de Agroecologia, 7(2), 112-125

Souza, S. T., Cassol, P. C., Baretta, D., Bartz, M. L. C., Klauberg Filho, O., Mafra, A. L., \& Rosa, M. G. (2016). Abundance and diversity of soil macrofauna in native forest, eucalyptus plantations, perennial pasture, integrated crop-livestock, and no-tillage cropping. Revista Brasileira de Ciência do Solo, 40. https://doi.org/0.1590/18069657rbcs20150248

Vargas, A. B., Chaves, D. A., Val, G. A., Souza, C. G., Farias, R. M., Cardozo, C., \& Menezes, C. E. G. (2013). Diversidade de artrópodes da macrofauna edáfica em diferentes usos da terra em Pinheiral, RJ. Acta Scientiae and Technicae, 1(2), 21-27. https://doi.org/10.17648/uezo-ast-v1i2.41

Verma, D., Yadav, R. K., \& Kumar, M. (2014). Effect of ecological factors on population density of collembolan in agra. Journal of Environmental and Applied Bioresearch, 2(1), 25-28 